\title{
Housing Market in the Time of Pandemic: A Price Gradient Analysis from the COVID-19 Epicentre in China
}

\author{
Ka Shing Cheung *(D), Chung Yim Yiu (D) and Chuyi Xiong $(\mathbb{D}$ \\ Department of Property, The University of Auckland Business School, Auckland 1010, New Zealand; \\ edward.yiu@auckland.ac.nz (C.Y.Y.); c.xiong@auckland.ac.nz (C.X.) \\ * Correspondence: william.cheung@auckland.ac.nz
}

Citation: Cheung, Ka Shing, Chung Yim Yiu, and Chuyi Xiong. 2021.

Housing Market in the Time of

Pandemic: A Price Gradient Analysis from the COVID-19 Epicentre in China. Journal of Risk and Financial Management 14: 108. https:// doi.org/10.3390/jrfm14030108

Academic Editor: Desmond Tsang

Received: 6 February 2021

Accepted: 2 March 2021

Published: 5 March 2021

Publisher's Note: MDPI stays neutral with regard to jurisdictional claims in published maps and institutional affiliations.

Copyright: (c) 2021 by the authors. Licensee MDPI, Basel, Switzerland. This article is an open access article distributed under the terms and conditions of the Creative Commons Attribution (CC BY) license (https:// creativecommons.org/licenses/by/ $4.0 /)$.

\begin{abstract}
While the outbreak of the COVID-19 disease has caused asset markets to experience an unprecedented spike of risk and uncertainty worldwide, the real estate market in many global cities appears to be immune to the adverse effects. How does COVID-19 affect urban housing markets? This study is a first attempt to identify the pandemic's impact on house prices by applying a price gradient analysis to the COVID-19 epicentre in China. Considering microlevel housing transaction data in 62 areas from nine districts in Wuhan City from January 2019 to July 2020, the hedonic pricing and the price gradient models suggest that there was, respectively, a $4.8 \%$ and a $5.0-7.0 \%$ year-on-year fall in house prices immediately after the pandemic outbreak. Although house prices rebounded after the lockdown period, the gradient models show that the price gradients were flattened from the epicentre to the urban peripherals. The price premiums in high-density areas were also substantially discounted after the city's lockdown. Our findings are robust to different model specifications. The implication is that the risk associated with the pandemic is localised and transitory in nature. People may be able to internalise the risk by residing in low-density residential areas.
\end{abstract}

Keywords: COVID-19; Wuhan China; house price gradient; revealed-preference

\section{Introduction}

A contagious disease, commonly known as the coronavirus disease (COVID-19 or SAR-COV-2), was first reported in the Wuhan Huanan seafood market in late 2019 (World Health Organization 2020). The spread of the disease led to an ongoing pandemic across the world. Governments worldwide imposed national or local area lockdown orders to restrict business operations and required households to "stay-at-home" for social distancing to limit interactions and curtail the spread of the virus. The pandemic is having an unprecedented impact on countries. At the time of writing (early 2021), not only had it led to over-million deaths, but the socioeconomic costs had already exceeded those in the global financial crises (United Nations Office for Disaster Risk Reduction UNODRR). This health emergency has affected almost every sector of all economies.

In theory, the lockdown orders should have altered property purchasing behaviours (Alexander and Karger 2020) and impacted businesses such as property agencies that involve face-to-face interactions (Koren and Petö 2020). Lockdown orders should inevitably disrupt the search processes of property buyers and subsequently lengthen sale completions. COVID-19 related factors should also introduce market frictions to the matching process and negatively affect the transacted prices and liquidity. Fang et al. (2020) also report a significant decline in mobility following the lockdown orders at the start of Wuhan's pandemic. Such market frictions can be characterised as a negative demand shock where buyers cannot conduct an optimal search and bidding process.

Intuitively, therefore, one may conjecture that the contagion rate of COVID-19 and the subsequent shutdowns would negatively affect residential markets ( $D^{\prime}$ Lima et al. 2020). However, in contrast to this common belief, house prices have surged upwards in almost all countries. For example, Knight Frank's (2020) Global House Price Index revealed that, even 
though most countries faced unprecedented economic devastation, $91.1 \%$ of the 56 sampled countries recorded house price increases year-on-year in Q2 2020. A commonly accepted explanation is that synchronised countercyclical measures, such as interest rate cuts by various central banks (to historic lows) after the pandemic outbreak, have disguised the real impacts of COVID-19 on house prices.

This study aims to identify the temporal and spatial impacts of COVID-19 on house prices at the virus's epicentre, i.e., Wuhan City in China. The Wuhan case is used because it can exclude all the effects of countercyclical measures, such as interest rate cuts and mortgage policy changes, and it can eliminate media effects from the global news reporting. Moreover, Wuhan's house prices exhibited an upward trend before the pandemic outbreak, which makes Wuhan an excellent case to show COVID-19's effects, if any, on house prices. The city's real estate market report suggests that in the first 11 months of 2019, the average sales price continued to increase by $12.2 \%$ year-on-year, with the supply of private housing dwindling by $2.7 \%$ (Sina 2020).

Furthermore, in order to control the confounding factors and endogeneity of housing prices arising from government responses, this study exploits the first reported epicentre of the pandemics as part of the identification strategies to reveal the adverse impact of the COVID-19 on asset prices. The coronavirus is novel, and the outbreak was highly localised at the time of initial occurrence. People living a few kilometres away were even unaware of what was happening at the epicentre. Therefore, the Wuhan case provides a temporal-spatial dimension of the spread of the price-shock. In other words, if the initial impact was localised in a small district, then the house price changes in the proximate districts can act as a counterfactual. In addition, this study has adopted a price gradient analysis to unveil the impacts of the pandemic on housing prices. The price gradient is a spatial-temporal differencing approach, i.e., a difference-in-differences setup with preand postpandemic period against a distance measured from the epicentre for controlling the spatial difference and the endogeneity involved. A price gradient analysis from the epicentre to the peripheral districts of Wuhan City offers us insights to reveal COVID-19's spreading effects on house prices, ceteris paribus.

Unlike other natural disasters that have an immediate known boundary around the affected areas, an infectious disease originates in a localised area, but every once in a while, there may develop as an outbreak that has a significant impact at either a local level as endemic, as an epidemic that spreads through several communities, or as a pandemic whose spread is global. The research question in this study is: how do people react to the spread of the spatially evolving risk? When a risk is localised, people can avoid it by moving elsewhere. However, when risk is spreading everywhere, how do people respond? This is the first attempt to answer this question since the last pandemic of "Spanish flu" of 1918.

The paper will be organised as follows. Section 2 critically reviews the literature on systematic risk, idiosyncratic risk, local risk, and price gradient analysis. Section 3 uses a simple model to develop the testable implications on how pandemic risk affects housing price gradients. Section 3 outlines the research design, empirical model, and data used. Section 4 discusses the empirical results. Section 5 further tests a nontrivial effect of the pandemic on people's preferences for living density. Section 6 concludes.

\section{Literature Review}

\subsection{The Impacts of COVID-19 on the Housing Market}

Pandemics are not new and occurred at different stages in human history (Ferguson et al. 2020). Since the outbreak of COVID-19, literature documented how the pandemic impacts various industries and the broader economy (Nicola et al. 2020; Ozili and Arun 2020; McKibbin and Fernando 2020; Liu et al. 2020). The mortality and morbidity effects of COVID-19 entail substantial economic losses (Viscusi 2020). Brodeur et al. (2020) has conducted a detailed literature review on the socioeconomic consequences of COVID19 and the corresponding government interventions, focusing on labour, health, gender, 
discrimination, and environmental aspects. In capital markets, Mazur et al. (2021) and Baker et al. (2020) have investigated the stock market performance and how firms react to the pandemic. Other studies compare the pandemic with other financial crises related to its connectedness to the global financial market (So et al. 2021; Zhang et al. 2020).

As economic development is closely associated with the housing market and the monetary policies often go in tandem with the housing market cycle (Chen and Wen 2017; Apergis 2021), studies started to explore the linkage between the pandemic and the property market (Yang and Zhou 2021; Wang 2021). Ling et al. (2020) have examined how the pandemic shock influences commercial real estate prices and found that the risk-adjusted returns for real estate investment trusts (REITs) significantly respond to the COVID-19 cases growth. The study further shows that while the returns of retail and hospitality REITs react negatively to the growing numbers of cases, the health care and technology REITs witnesses a positive return. Real estate development and management processes are also affected. Tanrıvermiş (2020) observed that the global supply chain disruptions have significantly delayed many development schedules, increased operation costs, and adversely affected the return rates of the real estate sector in Turkey. Uchehara et al. (2020) have studied the entire real estate supply chain under the stay-at-home policy. Their study revealed that the improvement of the contract clause could mitigate the pandemic risk across the real estate sector. Marona and Tomal (2020) found that the workflow of real estate brokers and the attitude of their clients are considerably affected by the pandemic.

Limited studies have observed the direct real estate price dynamics during the COVID19 pandemic, and most are analysing at an aggregate level. Yoruk (2020) used daily listing data from 50 major cities in the United States last April and found more than a 60\% drop in new home listings and pending home sales compared to the same period in the previous year. He further concludes that the housing market collapse is broad-based, hitting all major cities, regardless of the intensity of virus spread or timing of introducing state-level policies to combat the pandemic. Del Giudice et al. (2020) have predicted the housing price dynamic in Campania by applying the Lotka-Volterra model. The results showed that the housing price drop of $4.16 \%$ in the short run and $6.49 \%$ in the medium run. Zhao (2020) applied the zip code-level data and nonparametric estimation to show that the Federal Reserve's unprecedented monetary easing has accelerated the growth rate of median housing price from April to August 2020, which is faster than any four months in the lead-up to the 2007-2009 global financial crisis. The increase in housing demand in response to lower mortgage interest rates displays a structural break since the pandemic outbreak. This is also why we are using Wuhan as the case to study the effects of the pandemic on the housing market. No monetary policy was in place that concealed the adverse impacts of the pandemic.

Qian et al. (2021) applied a semi-log regression to the monthly average house prices of 1319 communities and found a $2.47 \%$ housing price discount of the communities with confirmed COVID-19 cases. Such a negative price effect only existed in the regions, either with a higher infection level or worse medical conditions. Huang et al. (2020b) have evaluated the housing market's performance in China after the COVID-19 outbreak and subsequent economic reopening. Using weekly housing price indices from 64 cities in China, this study found that the COVID-19 epidemic had a slightly negative effect on house prices but a strong negative effect on transaction volume. Yang and Zhou (2021) even suggested a positive impact of COVID-19 on housing prices in the second-and thirdtier cities in China. Nevertheless, they are using the average selling price of commercial housing at the city level, which did not consider the quality difference of properties. To the best of our knowledge, the impacts of the COVID-19 on the Wuhan housing market, the epicentre of the pandemic, seems to be under-researched so far.

\subsection{Systematic Risk, Idiosyncratic Risk, and Local Risk}

A fundamental concept in finance and economics is the relationship between risk and return. The greater the risk an investor is willing to take, the greater the potential 
return that is expected. Risks can be primarily categorised as systematic or unsystematic (Beja 1972). Systematic risk, also known as market risk, is vulnerable to events that affect broad market returns, aggregate income, and total resources allocations. Natural disasters such as earthquakes, tsunami, and hurricanes exert a systematic risk that affects resource allocations in many contexts. That is why systematic risk is sometimes called contingent risk. Unsystematic risk, often referred to as idiosyncratic risk, is confined to specific vulnerable agents or industries. Unsystematic risk is usually uncorrelated with overall market returns. Measuring and quantifying different risks allows investors, traders, and business managers to devise diversification strategies and use financial derivatives to hedge certain risks (Stulz 1996).

However, the COVID-19 pandemic differs from such conventional characterisation of risks in many ways. Rather than causing the widespread destruction of housing and infrastructure, the pandemic's impacts are caused by individuals' illnesses and deaths, economic downturn, and strains on health and governance systems. The scale and duration of the impacts associated with different sectors are also highly unequal and essentially contingent on locations, the spread of the disease, and evolving rates of new cases. Susskind and Vines (2020) suggest that the economic impact of COVID-19 is unequal. Del Rio-Chanona et al. (2020) suggest that demand shocks hit specific sectors such as transport, whereas supply shocks impact the manufacturing sector. Some industries are influenced by both: for instance, entertainment, restaurants, and tourism; while others and in particular, e-commerce and IT industry, are relatively immune from the pandemic.

While the global economy is in its deepest recession in decades since the Great Depression (Gopinath 2020), a divergent and contrary development in asset markets worldwide has drawn investors' attention. Despite the world economy being hard-hit, many asset prices, especially property, are rising for different reasons and according to different measures across the globe. House prices have manifested hardly any adverse impacts of the health crisis. In the second quarter of 2020, global real house price inflation remained growing, at 1.9\% year-on-year (Bank for International Settlements 2020). Real residential property prices even grow by $3.7 \%$ on average in advanced economies, the fastest year-onyear growth rate since 2016. No doubt, falling interest rates, increased investor activities, and the launch of significant fiscal and monetary containment measures have had impacts.

How have property markets reacted to the COVID-19 pandemic and to lockdowns and domestic economic measures intended to "flatten the curve" of infection? Property is a highly "localised asset." Tuzel and Zhang (2017) have developed a production-based equilibrium model for local markets to show that local factor prices respond to aggregate shocks differently, subject to the industry types dominating the area. The locations of firms significantly affect the risk, not at the aggregate level but through local factor prices. A significant part of physical capital, such as land and structures, is immobile. Production factors are constrained by geographical immobility, while local factors account for a large part of asset pricing. Fluctuations in local factor prices due to local economic conditions can have significant effects on the firms. Technically speaking, local markets have different compositions of beta risks.

\subsection{Price Gradient Analysis on the Property Market}

Urban economists have long studied the locational value of properties. Von Thünen (1826) pioneered the study of locational effects on central marketplaces. This early spatial theory of agriculture was then modernised by Alonso (1964) through bid-rent curve analysis. Many studies have since emerged from studies that have tested urban spatial models predictability by applying hedonic regressions and repeat sales methods. Mills (1967) developed a mathematical model based on Muth to illustrate the relationship between transportation and urban development patterns. Muth (1969) then attempted to estimate the housing price gradient for Chicago empirically. Muth controlled the factors that might affect the price gradient, such as proximity to public transportation and shopping centres, using dummy variables. None of these variables was significant at the five per cent level 
(in two-tailed $t$-tests). The proximity measures were crude and did not consider the heterogeneity of the housing. Other researchers have incorporated the heterogeneity of housing directly by using a hedonic pricing model. The housing price gradient can be estimated by regressing sale prices on housing structure characteristics, neighbourhood characteristics, and distance from the city centre. The coefficient on distance represents the slope of the price gradient.

Brueckner (1987) further presents a unified framework of the Muth-Mills model and shows that the per area unit price of housing $p$ drops with distance $x$ to the city centre and that this rate is a function of commuting costs per round-trip mile t. The model assumed that household consumption of housing $q$ is affected by some exogenous factors $\alpha$. Subsequently, urban sprawl has been observed and intensively studied. To measure American urbanisation, Mieszkowski and Mills (1993), Glaeser and Kahn (2004), and others have used estimates of the changing population density gradient. Various causes have been related to urban sprawl, including traffic congestion (Anas and Rhee 2006), quiet neighbourhoods in the suburbs (Couch and Karecha 2006), the availability of transport infrastructures (Anas and Pines 2008), the improvement of the economic base (Brueckner and Helsley 2011), and crime rates and changes in age and household structures (Jaeger and Schwick 2014).

Since the advent of the Alonso-Muth-Mills (AMM) model of the bid-rent curve, price gradient analysis has been commonly applied in real estate studies (Alonso 1964; Mills 1967; Muth 1969). It reflects the impacts of residential location choices on the price differentials. A downward sloping house price gradient from the city centre is generally observed (Manzoli and Mocetti 2019). Analysis of changes in the house price gradient over time can be considered a temporal-spatial differencing method (i.e., difference-in-differences), a ceteris paribus analysis. When a change in environment, such as in the transportation infrastructure or amenities in a district, is localised, then a price gradient change can reveal the net effects by taking the proximate districts as a control (Yiu and Wong 2005).

There have been very few studies on the impacts of an epidemic or pandemic on house prices, probably because of insufficient transactions during the incidents. Francke and Korevaar (2020) analyse the effects of the 16th-17th centuries plague in Amsterdam and 19th-century cholera in Paris and found a 5.5\% to $13.4 \%$ fall in house prices during the epidemic, but the price growth quickly returns to its long-term trend. However, epidemic dummies in hedonic and repeat-sales models do not allow the cross city spillover effects of the epidemic. Wong (2008) studied the impacts of the severe acute respiratory syndrome (SARS) viral disease on house prices in Hong Kong and found a 1.6\% reduction in price for the overall housing market, with an additional 3\% fall for the SARS-affected estates. However, to assess the epidemic's impacts on house prices, the study applied only a simple hedonic pricing model of 25-weeks before and after SARS, with a linear time trend, and it did not provide an appropriate control group to identify the change in price gradient. The study findings are also probably subject to confounding bias due to the mixing of the effect of SARS with extraneous risk factors associated with the Asian Financial Crisis in the early 2000s.

\section{Empirical Model}

\subsection{House Price Gradient Models}

Two methods of measuring these gradients are considered to examine the change in house price gradients from the epicentre after the pandemic's outbreak. A simple model is also presented in Appendix A to illustrate how the empirical model is motivated to set up. The first method is based on comparing house price differentials between districts, whereas the second method uses the distance from the epicentre. The baseline model is a semi-log hedonic model as specified in Equation (1) (Malpezzi 2002). The logarithm of the transacted price of housing unit $i$ in the district $d$ at time $t$ is the dependent variable, i.e., $\ln \left(P_{i, d, t}\right)$. There are three sets of typical explanatory variables, namely (1) $X_{k}$ the housing characteristics of housing unit $i$; (2) the district effects (D) at different district $d$; and (3) the 
time effects $(\mathrm{T})$ at different month $t$. The house price index is derived from the exponentials of the estimated coefficients $\theta$, and $\varepsilon$ are the error terms.

$$
\ln \left(P_{i, d, t}\right)=\alpha+\sum_{k=1}^{K} \beta_{k}\left(X_{k, i}\right)+\sum_{d=2}^{N} \gamma_{d}\left(D_{d i}\right)+\sum_{t=2}^{T} \theta_{t}\left(T_{t i}\right)+\varepsilon_{i, d, t} \ldots
$$

As the hedonic model cannot control the impacts of other simultaneous events, such as governments' bailout measures, we choose to analyse the changes in house price gradient after the incident's outbreak to preclude the spatial-temporal effects of other events. As Wuhan is the city with the first reported cases of COVID-19, its impacts on house prices would be localised at the epicentre in the first few weeks. The house price impacts are also expected to follow the spread of the COVID-19. It is worth noting that we have considered to include the spatial autocorrelation analysis. Nevertheless, as the spatial autocorrelation comes from the information spillover across spaces, and if a weighted distance matrix is used to capture the information shock from the pandemic, it will defeat the purpose of this study to examine such spillover across various areas and districts. Therefore, price gradient analysis is used instead.

Two gradient measures, viz. (1) District Gradient Model and (2) Distance Gradient Model will be adopted to test the hypothesis.

\subsubsection{Price Gradient among Districts (District Gradient Model)}

A difference-in-differences hedonic pricing model is specified to examine the COVID pandemic's impacts on the house price gradient across the district. Equation (2) is a semi$\log$ hedonic equation that serves as the district gradient model and includes the interaction effects between districts $D_{d}$ and periods $\rho_{m}^{C O V I D} . \alpha, \beta, \gamma, \theta, \delta$ and $\pi$ are the coefficients to be estimated, $\varepsilon$ are the error terms. To represent the periods before and after the outbreak, Equation (2) divides the data into two periods, one before November 2019 and the other in or after November 2019.

$$
\begin{aligned}
\ln \left(P_{i, d, t}\right)=\alpha+ & \sum_{k=1}^{K} \beta_{k}\left(X_{k, i}\right)+\sum_{d=2}^{N} \gamma_{d}\left(D_{d, i}\right) \\
& +\sum_{t=2}^{T} \theta_{t}\left(T_{t, i}\right)+\sum_{m=2}^{M} \delta_{m}\left(\rho_{m}^{C O V I D}\right)+\sum_{d=2}^{N} \sum_{m=2}^{M} \pi_{d m} \rho_{m}^{C O V I D} \times\left(D_{d, i}\right)+\varepsilon_{i, d, t} \ldots
\end{aligned}
$$

3.1.2. Price Gradient from the Epicentre (Distance Gradient Model)

As a robustness check, we construct another differences-in-difference hedonic pricing model to examine the impacts of the COVID pandemic on the house price gradients based on the distance from the epicentre. Equation (3) is a semi-log hedonic equation that serves as the baseline distance gradient model. The subject of interest is the interaction effects between distance $d_{i}^{\text {epictr }}$ and periods $\rho_{m}^{\text {COVID }} . \alpha, \beta, \gamma, \theta, \delta^{\prime}$ and $\pi^{\prime}$ are the coefficients to be estimated, $\varepsilon$ are the error terms. Like the district gradient model in Equation (2), the distance gradient model in Equation (3) will include the two periods, one before November 2019, and the other in or after November 2019.

$$
\ln \left(P_{i, d, t}\right)=\alpha+\sum_{k=1}^{K} \beta_{k}\left(X_{k, i}\right)+\sum_{d=2}^{N} \gamma_{d}\left(D_{d, i}\right)+\sum_{t=2}^{T} \theta_{t}\left(T_{t, i}\right)+\pi^{\prime} d_{i}^{\text {epictr }}+\sum_{m=2}^{M} \delta_{m}^{\prime} d_{i}^{e p i c t r} \times \rho_{m}^{\text {COVID }}+\varepsilon_{i, d, t} \cdots
$$

\subsection{Data}

The data used in this study are sourced from Homelink Real Estate Agency Co., Ltd. (namely "Lianjia" in Chinese) in Wuhan, China. Lianjia is one of the largest real estate brokerages in China, and its core business is second-hand property sales. The sample period of the data was from January 2019 to July 2020 (2019M1 to 2020M7). The data recorded residential property sales from nine districts in Wuhan and covered 62 areas with 25,860 transactions involved. The transaction data contained the characteristics of each property, including their housing characteristics, selling price, and, more importantly, 
the spatial information. The data is obtained from the public domain, and the brokerage heavily relies on the online platform to run their agency businesses. Potential buyers also utilise the information online to search and purchase properties; there is a strong incentive to report the transaction information on this online platform accurately. Over the decade, before the outbreak at the end of 2019, Wuhan's residential property market was very active, but the city was locked down during February and March 2020. Since April 2020, the housing market has rebounded strongly. The active housing market provides us with a comprehensive data set on recorded sales of housing transactions from the nine districts in Wuhan city between January 2019 to July 2020.

Table 1 shows the descriptive statistics of the data used. We include 62 areas (A1-A81) in the nine districts (D1-D9) which are the closest to the COVID-19 pandemic epicentre, with the distances of the houses from the epicentre ranging from $0.07 \mathrm{~km}$ to $35.84 \mathrm{~km}$ and on average $10.38 \mathrm{~km}$. Other districts further away from the epicentre are excluded. Wuhan city's area is about $10,699 \mathrm{sq} \mathrm{km}$, and the area of the studied districts is about $6696 \mathrm{sq} \mathrm{km}$; their population is more than 7.6 million. The 62 district-area sizes range from about one sq $\mathrm{km}$ to $1820 \mathrm{sq} \mathrm{km}$, and the average size is about $102 \mathrm{sq} \mathrm{km}$. The average number of households per sq $\mathrm{km}$ in the areas is about 7547, and the average number of buildings per $\mathrm{sq} \mathrm{km}$ in the areas is about 97 . In other words, there are on average about 77 households per building, indicating that the city density is moderate and the housing type is mostly high-rise high-density apartments. Figure 1 shows the price difference between the pre-and post-COVID-19 period across Wuhan city with communities shown.

Table 1. Descriptive statistics.

\begin{tabular}{|c|c|c|c|c|c|}
\hline Description & Variable & Mean & S.D. & Min & Max \\
\hline Sales Price $(\mathrm{RMB} \times 10,000)$ & $P_{i t}$ & 166.93 & 94.79 & 11.50 & 2200.00 \\
\hline Size $(\mathrm{sq} \mathrm{m})$ & $S I Z E_{i}$ & 90.85 & 32.89 & 7.35 & 679.06 \\
\hline Living room (No.) & $L R M_{i}$ & 1.60 & 0.53 & 0.00 & 5.00 \\
\hline Bedroom (No.) & $B R M_{i}$ & 2.38 & 0.80 & 1.00 & 8.00 \\
\hline Bathroom (No.) & $B A R M_{i}$ & 1.25 & 0.47 & 0.00 & 8.00 \\
\hline Kitchen (No.) & $K I T_{i}$ & 1.00 & 0.09 & 0.00 & 4.00 \\
\hline Building age (year) & $A G E_{i}$ & 10.72 & 6.88 & 0.00 & 80.00 \\
\hline Subway $(1=$ yes; $0=$ no $)$ & $S W_{i}^{i}$ & 0.64 & 0.48 & 0.00 & 1.00 \\
\hline Tax wavier $(1=$ yes; $0=$ no $)$ & $T W_{i}$ & 0.26 & 0.44 & 0.00 & 1.00 \\
\hline Building direction & $D I R_{i}$ & \multirow{2}{*}{\multicolumn{4}{|c|}{$\begin{array}{l}8 \text { Directions } \mathrm{N}, \mathrm{NE}, \mathrm{E}, \mathrm{SE}, \mathrm{S}, \mathrm{SW}, \mathrm{W}, \mathrm{NW} \\
62 \text { areas } \mathrm{A} 1, \ldots, \mathrm{A} 81 \text { in } 9 \text { districts D1, . . , D9 }\end{array}$}} \\
\hline Area and District & $D_{a}$ and $D_{d}$ & & & & \\
\hline Distance from the epicentre $(\mathrm{km})$ & $d_{i}^{\text {epictr }}$ & 10.38 & 6.95 & 0.07 & 35.84 \\
\hline Size of Area (sq km) & $A_{a}$ & 102.06 & 303.96 & 0.89 & 1820.95 \\
\hline Population in area & $P O P_{a}$ & 103,762 & $84,668.03$ & 2461.00 & $314,096.00$ \\
\hline Household density (per sq km) & $H_{a} / A_{a}$ & 7546.51 & 6662.27 & 16.39 & $26,586.27$ \\
\hline Building density (per sq km) & $B_{a} / A_{a}$ & 77.38 & 25.46 & 25.93 & 180.10 \\
\hline
\end{tabular}

Notes: The descriptive statistics are based on the residential property transactions in Wuhan from the nine districts from January of 2019 to July of 2020. The subscript $i$ stands for the transacted housing unit $i$; subscripts $a$ and $d$ stand for the Area and District where the housing unit is located, respectively. The descriptive statistics of Panel A are based on the transaction records; that of Panel B is based on the 81 Areas of Wuhan. 


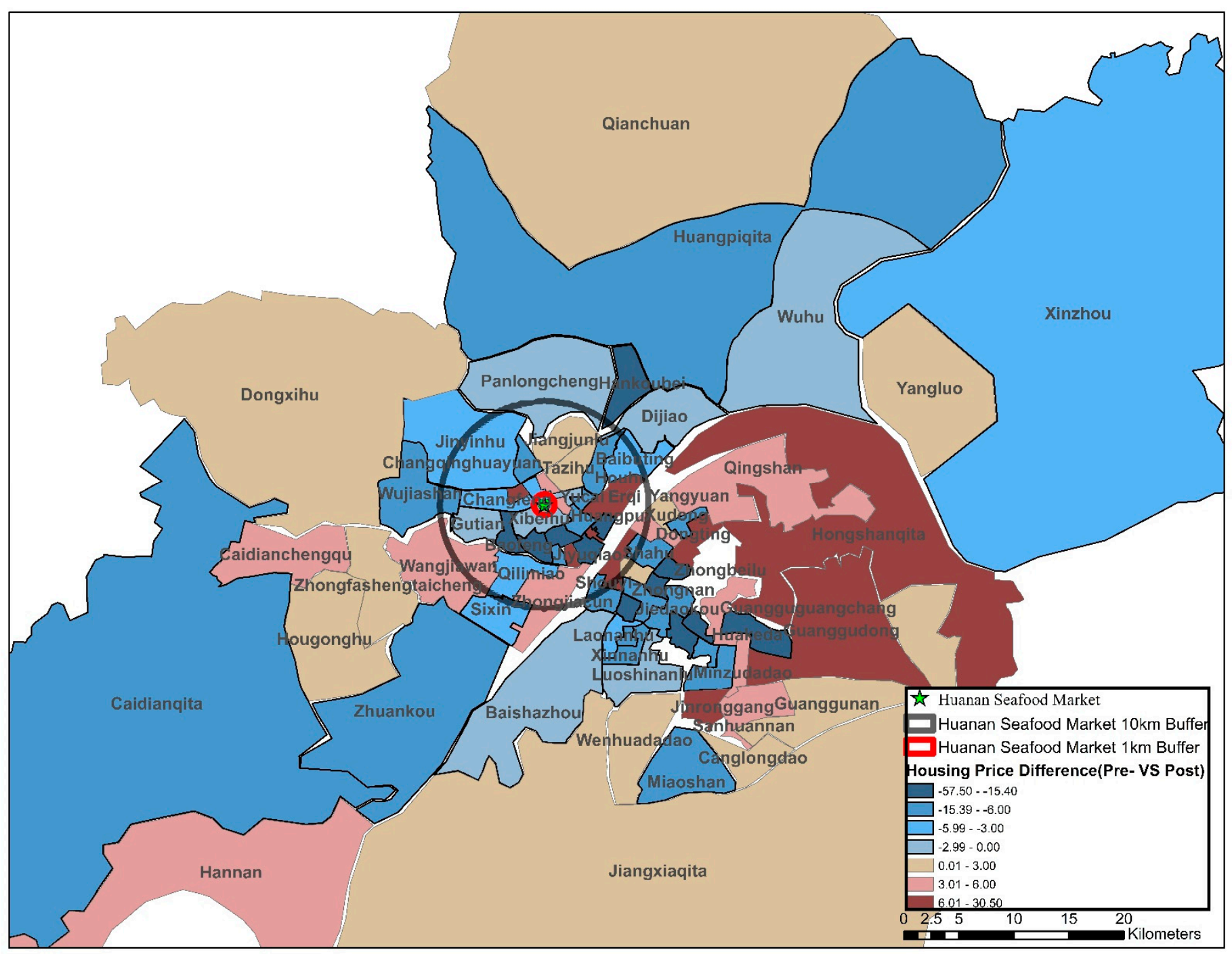

Figure 1. Price difference between the pre and post pandemic period across Wuhan city.

The residential property transaction data is divided into two subsample periods. One is the 10-month period ( $p 1)$ before the pandemic outbreak, i.e., from January to October 2019 , the other is the 9-month period ( $p 2$ ) after the pandemic outbreak, i.e., from November 2019 to July 2020. According to data gathered from one of the most representative real estate companies, HomeLink, in Wuhan City, there were 25,860 valid transactions in these 19 months (i.e., 13,773 transactions in subperiod $p 1$, and 12,087 transactions in subperiod p2). Figure 1 shows the housing price differences between pre-and post-COVID-19 periods across Wuhan City. Figure 2 shows the numbers of housing transactions in each district in the period. It indicates a decline of about $49 \%$ month-on-month in January 2020, and there were no transactions in February and March, corresponding to the lockdown period from 23 January to 8 April 2020. 


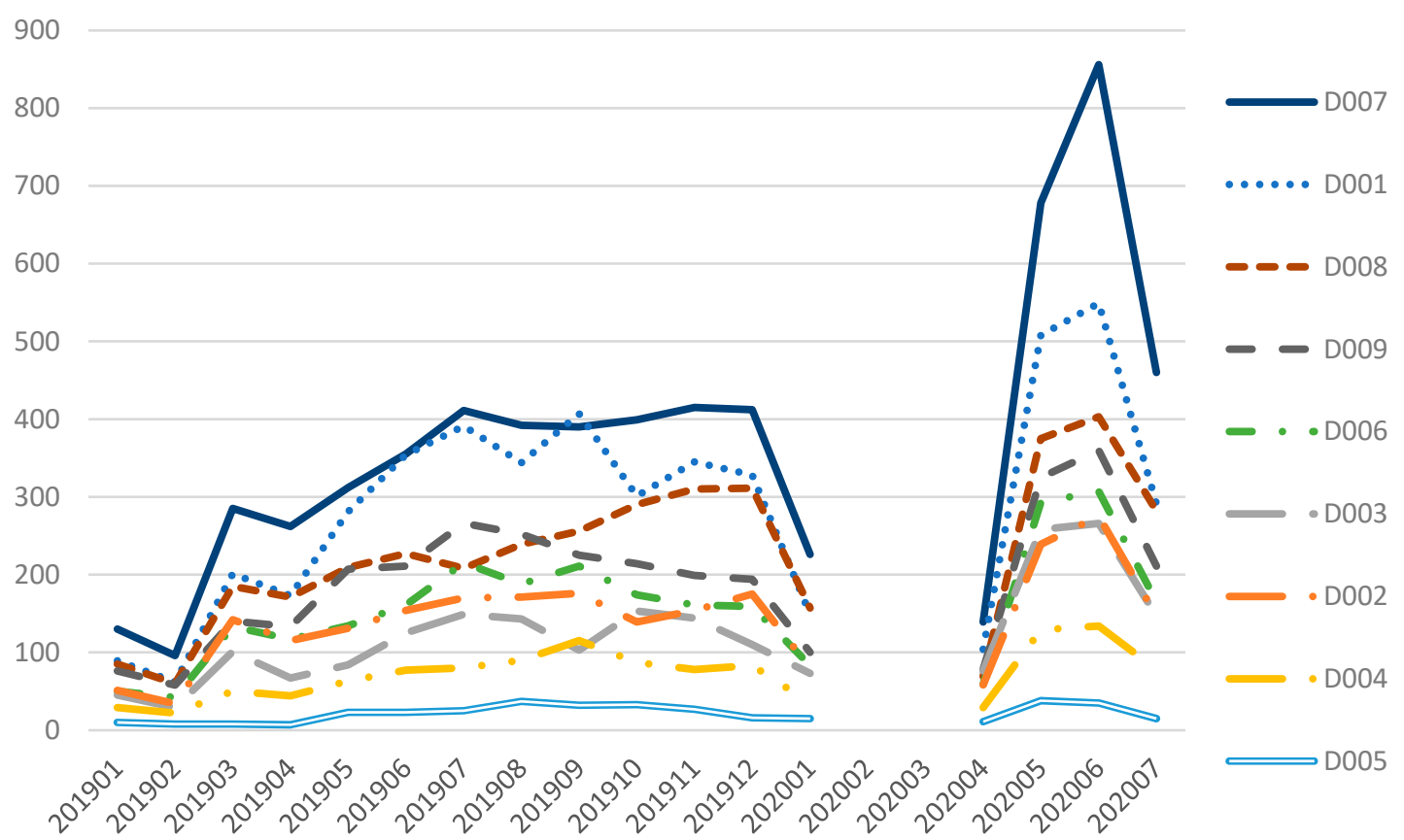

Figure 2. Numbers of Sales by Districts of Wuhan. Source: HomeLink 2020; Notes: Total numbers of housing units transacted in the nine districts from January 2019 to July 2020. The transaction data in February and March is not available due to the city lockdown.

Table 2 further shows the number of houses in each district and how far they are located from the epicentre. For example, D2 and D4 are closer to the epicentre, D6 and D9 are in the middle, while D3 and D5 are further away. The average transacted price is about RMB 1.67 million in this period, with the average property size being $91 \mathrm{sq} \mathrm{m}$. The transacted properties are relatively new, with an average building age of about 11 years. The accessibility variable SUBWAY is also included in our modelling, which is a dummy indicating whether the property is situated nearby a subway station. Another variable is a tax waiver indicator TAX_WAIVE which indicates whether the houses meet the needs of both the land-value increment tax waiver and the income tax waiver. These variables can better control the effect of tax policies on the transacted prices. The dataset provides ample information on the structural and locational characteristics so that a hedonic index can be estimated for our comparison purposes.

Table 2. Relationships between districts and distance from the epicenter.

\begin{tabular}{ccccccccc}
\hline Di & {$[\mathbf{0 , 5}$} & {$[\mathbf{5 , 1 0 )}$} & {$[\mathbf{1 0 , 1 5 )}$} & {$[\mathbf{1 5 , 2 0 )}$} & {$[\mathbf{2 0 , 2 5 )}$} & {$[\mathbf{2 5}, \mathbf{3 0})$} & {$[\mathbf{3 0 ,} \mathbf{3 5})$} & Total \\
\hline D1 & 2334 & 2446 & 97 & 0 & 0 & 0 & 0 & 4877 \\
D2 & 2276 & 135 & 0 & 0 & 0 & 0 & 0 & 2411 \\
D3 & 0 & 0 & 0 & 0 & 464 & 1357 & 252 & 2073 \\
D4 & 777 & 446 & 0 & 0 & 0 & 0 & 0 & 1223 \\
D5 & 0 & 0 & 0 & 0 & 0 & 238 & 122 & 363 \\
D6 & 750 & 1736 & 166 & 0 & 0 & 0 & 0 & 2652 \\
D7 & 0 & 313 & 2966 & 2747 & 192 & 0 & 0 & 6218 \\
D8 & 0 & 1787 & 2050 & 0 & 0 & 0 & 0 & 3837 \\
D9 & 0 & 2376 & 873 & 0 & 0 & 0 & 0 & 3249 \\
\hline Total & 6137 & 9239 & 6152 & 2747 & 656 & 1595 & 374 & 26,903 \\
\hline
\end{tabular}

Notes: The distances of the transacted houses from the epicentre in each district are grouped in distance brackets from $[0,5)$ to $[30,35) \mathrm{km}$. 


\section{Empirical Results and Discussion}

The Distance Gradient Model and the District Gradient Model are estimated using the ordinary least square (OLS) technique. Column (1) of Table 3 shows the results from the baseline hedonic model, and columns (2) and (3) present the corresponding two gradient models. The positive signs of all $\gamma_{d}$ except for D5 in the Hedonic Model by the district in column (1a) show that from January 2019 to July 2020, house prices in D5 were the lowest, as it is farthest away from the epicentre ( $29.5 \mathrm{~km}$ on average) among the nine districts (the omitted district D3 is the second farthest from the epicentre, $27.0 \mathrm{~km}$ ).

Table 3. Results of the Hedonic and House Price Gradient Models.

\begin{tabular}{|c|c|c|c|c|c|c|}
\hline & (1a) & (1b) & (2a) & (2b) & (3a) & $(3 b)$ \\
\hline Variable & \multicolumn{2}{|c|}{ Hedonic } & \multicolumn{2}{|c|}{ District Gradient } & \multicolumn{2}{|c|}{ Distance Gradient } \\
\hline $\mathrm{d}$ & & & & & $-0.020(-27.17) * * *$ & $-0.023(-23.17) * * *$ \\
\hline$d \times p 2$ & & & & & $0.0002(0.39)$ & $-0.0001(-0.30)$ \\
\hline D1 & $0.340(50.77)^{* * *}$ & & $0.341(37.23)^{* * *}$ & & $-0.078(-4.77)^{* * *}$ & \\
\hline D2 & $0.334(44.12)^{* * *}$ & & $0.357(34.46)^{* * *}$ & & $-0.145(-7.76)^{* * *}$ & \\
\hline D3 & omitted & & omitted & & omitted & \\
\hline D4 & $0.244(27.66)^{* * *}$ & & $0.262(21.78)^{* * *}$ & & $-0.191(-10.76)^{* * *}$ & \\
\hline D5 & $-0.720(-51.61) * * *$ & & $-0.697(-38.24) * * *$ & & $-0.664(-47.70) * * *$ & \\
\hline D6 & $0.099(13.90) * * *$ & & $0.096(9.87)^{* * *}$ & & $-0.304(-19.04) * * *$ & \\
\hline D7 & $0.369(59.46)^{* * *}$ & & $0.370(42.36)^{* * *}$ & & $0.125(11.76)^{* * *}$ & \\
\hline D8 & $0.562(80.79)^{* * *}$ & & $0.571(59.49)^{* * *}$ & & $0.239(17.91)^{* * *}$ & \\
\hline D9 & $0.221(31.80)^{* * *}$ & & $0.213(22.38)^{* * *}$ & & $-0.129(-9.10)^{* * *}$ & \\
\hline A6 & & $0.677(37.42)^{* * *}$ & & $0.662(26.00)^{* * *}$ & & $0.104(3.44)^{* * *}$ \\
\hline A7 & & $0.494(30.05)^{* * *}$ & & $0.596(26.58)^{* * *}$ & & $-0.063(2.18)^{* *}$ \\
\hline A17 & & $0.573(37.00)^{* * *}$ & & $0.626(29.93)^{* * *}$ & & $-0.076(-2.40) * *$ \\
\hline A21 & & $0.426(21.77)^{* * *}$ & & $0.481(17.59) * * *$ & & $-0.225(6.66)^{* * *}$ \\
\hline A20 & & $-0.730(-47.28)^{* * *}$ & & $-0.670(-32.00)^{* * *}$ & & $-0.718(-46.93) * * *$ \\
\hline A47 & & omitted & & omitted & & omitted \\
\hline $\mathrm{D} 1 \times \mathrm{p} 2$ & & & $0.009(0.74)$ & & & \\
\hline $\mathrm{D} 2 \times \mathrm{p} 2$ & & & $-0.036(-2.49) * *$ & & & \\
\hline $\mathrm{D} 3 \times \mathrm{p} 2$ & & & $0.003(0.27)$ & & & \\
\hline $\mathrm{D} 4 \times \mathrm{p} 2$ & & & $-0.030(-1.72) *$ & & & \\
\hline $\mathrm{D} 5 \times \mathrm{p} 2$ & & & $-0.050(-1.76) *$ & & & \\
\hline $\mathrm{D} 6 \times \mathrm{p} 2$ & & & $0.009(0.67)$ & & & \\
\hline $\mathrm{D} 7 \times \mathrm{p} 2$ & & & $0.008(0.69)$ & & & \\
\hline $\mathrm{D} 8 \times \mathrm{p} 2$ & & & $-0.006(0.43)$ & & & \\
\hline $\mathrm{D} 9 \times \mathrm{p} 2$ & & & $0.028(2.02)^{* *}$ & & & \\
\hline $\mathrm{A} 6 \times \mathrm{p} 2$ & & & & $0.118(3.39)^{* * *}$ & & \\
\hline $\mathrm{A} 7 \times \mathrm{p} 2$ & & & & $-0.129(4.07) * * *$ & & \\
\hline $\mathrm{A} 17 \times \mathrm{p} 2$ & & & & $-0.029(-0.96)$ & & \\
\hline $\mathrm{A} 21 \times \mathrm{p} 2$ & & & & $-0.024(-0.63)$ & & \\
\hline $\mathrm{A} 20 \times \mathrm{p} 2$ & & & & $-0.068(-2.22)^{* *}$ & & \\
\hline $\mathrm{A} 47 \times \mathrm{p} 2$ & & & & $0.001(0.04)$ & & \\
\hline Structure F.E. & \multirow{3}{*}{\multicolumn{2}{|c|}{$\begin{array}{c}\text { Yes } \\
\text { Yes (Monthly) } \\
\text { Yes }\end{array}$}} & \multirow{3}{*}{\multicolumn{2}{|c|}{$\begin{array}{c}\text { Yes } \\
\text { Yes (Quarterly) } \\
\text { Yes }\end{array}$}} & \multirow{3}{*}{\multicolumn{2}{|c|}{$\begin{array}{c}\text { Yes } \\
\text { Yes (Monthly) } \\
\text { Yes }\end{array}$}} \\
\hline Time F.E. & & & & & & \\
\hline District F.E. & & & & & & \\
\hline Adj. R-Sq & 0.751 & 0.821 & 0.751 & 0.8095 & 0.758 & 0.825 \\
\hline No. of Obs. & 25,860 & 25,860 & 25,860 & 25,860 & 25,860 & 25,860 \\
\hline
\end{tabular}

Notes: Figures in the parentheses represent the t-statistics of the estimates. ${ }^{* * *}, * * *$ represent statistical significance at the $1 \%, 5 \%$ and $10 \%$ levels. D1-D9 estimate District Effects, A1-A81 estimate Area Effects, and D3 and A47 are the omitted variables. For clarity, only the areas closest to (A17, A21), mid-range from (A6, A7) and furthest from (A20, A47), the epicentre is shown. p1 and p2 represent the period before 2019M11 and in and after 2019M11, respectively. These two periods are taken as the periods before and after the outbreak of COVID-19 because the first reported confirmed case of the pandemic was on 1 December 2019 (Huang et al. 2020a). The time fixed effects (monthly) are plotted in Figure 3.

Geographically D1, D2 and D7, D8 are the four highest-priced districts before the pandemic, as they are located at the two city centres separated by the Yangtze River. Similarly, in the Hedonic Model by area in column (1b), the house prices in the epicentre $\left(\mathrm{A} 17, \mathrm{~A} 21, \bar{d}_{i}^{\text {epictr }}=1.33,1.16\right)$ were about $57.3 \%$ and $42.6 \%$ higher than that in the peripheral areas $\left(\mathrm{A} 47, \bar{d}_{i}^{\text {epictr }}=29.11\right)$. Besides these three areas, we also reported another farthest area, A20 $\left(\bar{d}_{i}^{\text {epictr }}=29.49\right)$ and two areas of middle-range distance, A6 and A7 $\left(\bar{d}_{i}^{\text {epictr }}=4.23,5.05\right)$. They form three-pair of Areas from short to long distance from the epicentre.

The hedonic results consider only the overall house price gradient but do not consider the change in gradient after the pandemic outbreak. To examine house prices before (p1) and after (p2) the outbreak in each district, the District Gradient Model (2a) is estimated, using the interaction terms between each district and postoutbreak period (i.e., $\mathrm{D} \times \mathrm{p} 2 \mathrm{in}$ 
Table 3). The period after the outbreak shows an inverted price gradient from the epicentre to the peripherals. For example, the house price difference between D5 and D2 (the farthest and the closest) after the outbreak became $-1.4 \%(-5.0 \%+3.6 \%)$ compared with $-105.4 \%$ before the pandemic outbreak. Similarly, the results are consistent in the District Gradient Model by area (2b). The price level in the areas closest to the epicentre (A17, A21) has noticeably overturned from a positive $(62.6 \%, 48.1 \%)$ before the outbreak to a negative $(-2.9 \%,-2.4 \%)$ after the outbreak. The results are consistent with the fact that the Huanan Seafood Market is located at the A17 (Xibeihu), and the A21 (Xinhualu) is an area adjacent to A17. In the Areas (A6, A7), which are about $5 \mathrm{~km}$ from the epicentre, the price levels have fallen from $66.2 \%$ to $11.8 \%$ and $59.6 \%$ to $-12.9 \%$, respectively. The price drop in these two areas is probably due to their concentrated hospital facilities. There are three hospitals, namely the General Hospital of the Yangtze River Shipping, the Airborne Hospital of People's Liberation Army of China, and the Central Hospital of People's Liberation Army of China are located in Area 6 (Huangpuyongqing). In particular, the Central Hospital of the People's Liberation Army of China is one of five main hospitals receiving COVID-19 patients in the early stages of the pandemic outbreak. Area 7 (Qianjinjianghan, which belongs to the Jianghan District D2) was the district with the most infected cases among the districts on the left bank of Yangtze River (Wuhan Municipal Health Commission 2020). In addition, the Central Hospital of Wuhan was reported to receive some of the earliest cases of COVID-19. Indeed, if households are concerned about the spread of the virus, they will avoid purchasing properties in these areas or imposing substantial discounts on prices which sellers would accept.

In contrast, the price levels have risen from $-67.0 \%$ to $-6.8 \%$ in Area 20 (Yangluo) while remained flattened in Area 47 (Canglongdao, at $0 \%$ to $0.10 \%$ ). They were the two areas farthest away from the reported epicentre, i.e., the Huanan Seafood Market. Canglongdao (A47) belongs to D3 (Jiangxia District) and Yangluo (A20) belongs to D5 (Xinzhou District). Both D3 and D5 are also the two districts with the least reported infected cases on the right bank of the Yangtze River. A20 is the new economic development zone at the fringe of Wuhan city, where mainly plants and factories are located. Canglongdao (A47) is also known as the University Town of locals of Wuhan, and there are eight universities located in A47 without any large-scale hospital facilities in this area. All these area dummies are relative to the price level in Area 47 in the preoutbreak period. In the Distance Gradient Models, the results of both the district fixed-effect model $3 a$ and the area fixed-effect model $3 b$ show a switch of the distance gradients from negative to zero gradients. This finding implies that house prices near the epicentre before the outbreak were higher than those in the peripheral districts (a negative gradient of $-2.0 \%$ to $-2.3 \%$ per $\mathrm{km}$ by the two models) but lower than the peripheral districts after the outbreak (a positive gradient of $0.02 \%$ to $-0.01 \%$ per $\mathrm{km}$ by the two models), ceteris paribus. Indeed, there may be a concern whether the difference-in-differences method is an appropriate structural change model in analysing the impact of pandemic, in particular if the "common support" assumption holds (e.g., see Leung et al. 2007, 2011). On the stability of the implicit prices of housing attributes, we further compare the coefficients of the hedonic pricing model by stratifying the sample into pre- and post- pandemic period. The coefficients are very much similar and provide with the evidence that the common support assumption holds.

Figure 3 plots the house price indices estimated by the Hedonic and District Gradient Models by taking exponentials of the estimated coefficient $\theta_{t}$, over the sample period. The indices share a highly similar trend and turning points both before and after the lockdown. However, as there were no transactions during the two months of lockdown, it does not reflect the actual extent of the decline. After trading activities resumed, the indices indicate a 4.8\% year-on-year fall in house prices in April 2020 (Hedonic Model) or a 5.0-7.0\% fall (Distance Gradient Model), without considering the two-month lockdown period effect. This decline is much more substantial than the 1.6\% fall (25-week-on-25-week) due to SARS in Hong Kong in 2003 (Wong 2008). These findings support the hypothesis of a negative impact of COVID-19 on house price gradient. The observed housing prices increase in 
many countries during the pandemic outbreak due to other concurrent events, such as the interest rate cuts by various central banks. These results suggest that further studies of the effect of pandemic risk on asset pricing are warranted.

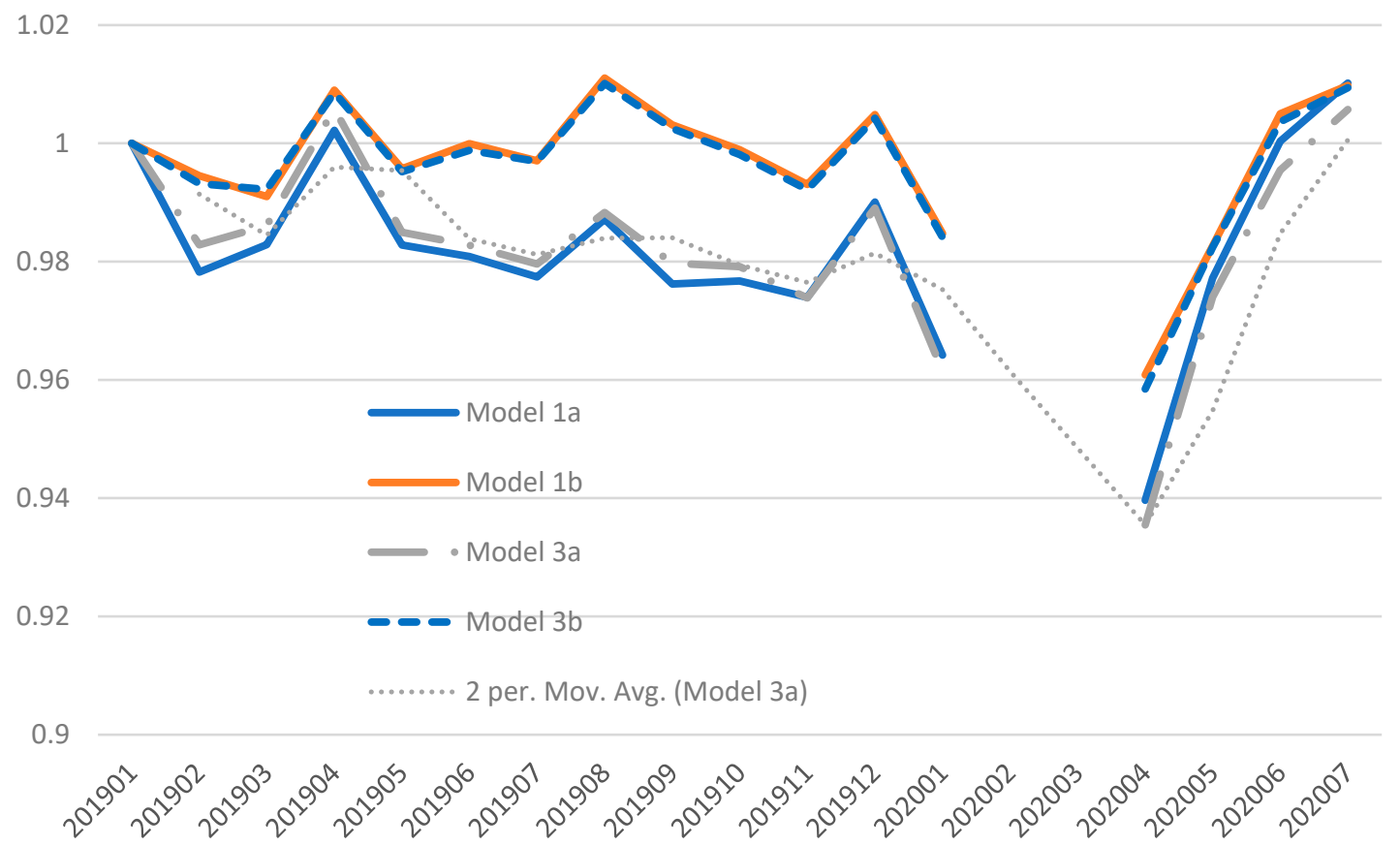

Figure 3. House price indices (HPIs) for Wuhan from 2019M1 to 2020M7 by Hedonic and Distance Gradient Models. Notes: The house price indices estimated by the HEDONIC and DISTANCE Models are shown. The continuous dotted curve refers to the two-period moving average of the estimates of Model 3a, excluding the effect of the two-month lockdown period.

\section{When Risks Are Everywhere, Do People Internalise Them? A Test on Living Density}

The price gradient analyses reveal that house prices in the epicentre fell relative to the peripherals, even though the prices rebounded after the lockdown. A tenable explanation is that people sort themselves spatially to avoid high-density communities. People will spatially choose to reside in the low-density area at equilibrium. We therefore further conducted a density test on the three models, viz. a household density test. The estimated coefficients are shown in Table 4. Household density is defined as the number of households per sq $\mathrm{km}$ of an area $\left(H_{a} / A_{a}\right)$. Since the densities are the same in each area, the location dummy variables can only be at the district level. All three models show that a housing unit in a high-density area has a price premium, irrespective of the household density. However, after the outbreak, the household density premium becomes a discount in both the Hedonic and the Distance Gradient models (the postoutbreak density coefficient in the District Gradient model is insignificant), revealing that people have become less willing to pay to purchase house units in high-density areas after the outbreak. 
Table 4. Results of the density models.

\begin{tabular}{|c|c|c|c|c|c|c|}
\hline \multirow[b]{3}{*}{ Variable } & \multicolumn{2}{|c|}{ (1c) } & \multicolumn{2}{|c|}{ (2c) } & \multicolumn{2}{|c|}{ (3c) } \\
\hline & \multicolumn{2}{|c|}{ Hedonic Density } & \multicolumn{2}{|c|}{ District Gradient } & \multicolumn{2}{|c|}{ Distance Gradient } \\
\hline & Coeff. & t-Stat & Coeff. & t-Stat & Coeff. & t-Stat \\
\hline$H_{a} / A_{a}$ & $9.14 \times 10^{-6}$ & $(21.25)^{* * *}$ & $8.65 \times 10^{-6}$ & $(18.28)^{* * *}$ & $6.88 \times 10^{-6}$ & $(14.84)^{* * *}$ \\
\hline$H_{a} / A_{a} \times p 2$ & $-9.35 \times 10^{-7}$ & $(-1.78) *$ & $1.51 \times 10^{-7}$ & $(0.23)$ & $-9.97 \times 10^{-7}$ & $(-1.65) *$ \\
\hline$d$ & & & & & -0.016 & $(-20.68)^{* * *}$ \\
\hline$d \times p 2$ & & & & & -0.0002 & $(-0.41)$ \\
\hline D1 & 0.278 & $(39.36)^{* * *}$ & 0.275 & $(28.31)^{* * *}$ & -0.042 & $(-2.59)^{* * *}$ \\
\hline D2 & 0.246 & $(29.80)^{* * *}$ & 0.265 & $(23.36)^{* * *}$ & -0.116 & $(-6.27)^{* * *}$ \\
\hline D3 & omitted & & omitted & & omitted & \\
\hline D4 & 0.160 & $(17.20)^{* * *}$ & 0.177 & $(13.83)^{* * *}$ & -0.168 & $(-9.51)^{* * *}$ \\
\hline D5 & -0.714 & $(-51.73)^{* * *}$ & -0.694 & $(-38.66)^{* * *}$ & -0.670 & $(-48.44)^{* * *}$ \\
\hline D6 & 0.081 & $(11.48)^{* * *}$ & 0.078 & $(8.05)^{* * *}$ & -0.239 & $(-14.67)^{* * *}$ \\
\hline D7 & 0.322 & $(50.18) * * *$ & 0.320 & $(35.92) * * *$ & 0.138 & $(13.00)^{* * *}$ \\
\hline D8 & 0.500 & $(68.47)^{* * *}$ & 0.505 & $(50.00)^{* * *}$ & 0.256 & $(19.24)^{* * *}$ \\
\hline D9 & 0.188 & $(26.87)^{* * *}$ & 0.178 & $(18.68)^{* * *}$ & -0.086 & $(-5.98)^{* * *}$ \\
\hline $\mathrm{D} 1 \times \mathrm{p} 2$ & & & 0.008 & $(0.55)$ & & \\
\hline $\mathrm{D} 2 \times \mathrm{p} 2$ & & & -0.040 & $(-2.46)^{* *}$ & & \\
\hline $\mathrm{D} 3 \times \mathrm{p} 2$ & & & 0.003 & $(0.21)$ & & \\
\hline $\mathrm{D} 4 \times \mathrm{p} 2$ & & & -0.035 & $(-1.89)^{*}$ & & \\
\hline $\mathrm{D} 5 \times \mathrm{p} 2$ & & & -0.053 & $(-1.87) *$ & & \\
\hline $\mathrm{D} 6 \times \mathrm{p} 2$ & & & 0.008 & $(0.56)$ & & \\
\hline $\mathrm{D} 7 \times \mathrm{p} 2$ & & & 0.005 & $(0.36)$ & & \\
\hline $\mathrm{D} 8 \times \mathrm{p} 2$ & & & -0.008 & $(-0.58)$ & & \\
\hline $\mathrm{D} 9 \times \mathrm{p} 2$ & & & 0.022 & $(1.58)$ & & \\
\hline Structural F.E. & & & & & & \\
\hline Time F.E. & Yes (I & hly) & Yes ( & erly) & Yes (I & thly) \\
\hline Location F.E. & Yes ( & cict) & & & Yes ( & rict) \\
\hline Adj. R-Sq & & & & & & \\
\hline No. of Obs. & & & & & & \\
\hline
\end{tabular}

Notes: Figures in parentheses represent the t-statistics of the estimates. ${ }^{* * *}, * * *{ }^{*}$ represent statistical significance at the $1 \%, 5 \%$ and $10 \%$ levels. D1-D9 estimate District Effects, D3 is the omitted variable. p1 and p2 represent the period before 2019M11 and in and after 2019M11, respectively. These two periods are taken as the periods before and after the outbreak of COVID-19, as the first reported confirmed case of the pandemic was on December 2019 (Huang et al. 2020a).

\section{Conclusions}

This study is an initial attempt to conduct a revealed preference analysis regarding the impact of pandemic risk on residential property markets using a price gradient approach. The last pandemic was already traced back to the Spanish flu in 1918 when there was no proper housing transaction data. The importance of studying the impact of the COVID19 risk on house prices lies in the spatial spreading characteristics of a pandemic. The pandemic is different from other natural disasters in that the affected areas do not have a spatial boundary. Natural disasters, such as earthquakes and tsunami, are typically confined within specific localised areas, such that people can avoid the risk by moving away from those areas. Even an epidemic like the SARS in Hong Kong in 2003 is a local crisis, so that the impact on asset prices was limited to the territories affected. However, a pandemic that originated in a local area may be spread worldwide. When risk can be spread without boundaries, how will people react?

Indeed, it is challenging to reveal people's preferences for the spread of the risk. On the one hand, governments introduce various countercyclical measures to bail out the residential property markets. On the other hand, people will react before the pandemic spreads to their cities when they learn the disease's devastating nature from the media. One approach to tackle such complications is identifying the virus infection's initial time and location when it is still a localised risk. Neither governments' countercyclical measures nor news reports will influence people's preferences. 
This study exploits the residential property transaction data in Wuhan city for several months before and after the first case of the COVID-19 pandemic was reported. COVID19 was first reported at a seafood market in Wuhan city which we assumed to be the epicentre in this study. The impacts of the outbreak on house prices in the epicentre are found to be significantly reduced by 5.0-7.0\% year-on-year by the price gradient model. Although the whole city's house prices rebounded after the lockdown, the price gradient from the epicentre to the urban peripherals was flattened. The finding reveals that people will change their preferences even though the risk is no longer confined to the epicentre. When the risk is everywhere, why do people nevertheless try to avoid the epicentre? This phenomenon is conjectured to be related to people's preference in spatially sorting themselves into low-density residential areas to avoid the risk of being infected. The price premium for high household density areas is found to be reduced and becomes negative after the lockdown, which confirms our conjecture and shows that people will attempt to mitigate the risks even though it is spatially unavoidable.

Author Contributions: For research articles with several authors, Conceptualisation, K.S.C. and C.Y.Y.; methodology, C.Y.Y.; software, C.X.; validation, K.S.C., C.Y.Y. and C.X.; formal analysis, K.S.C. and C.Y.Y.; investigation, K.S.C. and C.Y.Y.; resources, C.X.; data curation, K.S.C., C.Y.Y. and C.X.; writing-original draft preparation, C.Y.Y.; writing—review and editing, K.S.C., C.Y.Y.; visualisation, C.X.; supervision, K.S.C.; project administration, K.S.C.; funding acquisition, K.S.C. and C.Y.Y. All authors have read and agreed to the published version of the manuscript.

Funding: This research was funded by the University of Auckland Faculty Research Development Funds, grant number FRDF-3722103; and the same funding for the APC.

Institutional Review Board Statement: Not applicable.

Informed Consent Statement: Not applicable.

Data Availability Statement: Not applicable.

Conflicts of Interest: The authors declare no conflict of interest.

\section{Appendix A. A Toy Model That Motivates Price Gradient Analysis}

To motivate our housing price gradient analysis, we illustrate our thought with a simple toy model. Our model is in line with O'Sullivan (2007). The model assumes that all agents are homogenous and have the same income level. People are simply a tradeoff between the cost of medicine and house rents. It is worth noting that while some heterogeneous agent models (such as Hanushek and Yilmaz 2007; Gong and Leung 2020) could be more appropriate than homogeneous agent models (such as O'Sullivan 2007), the simple model here is used for motivating our price gradient analysis.

The model starts with a utility function for households, which is denoted by $u$, and depends on the demand for housing consumption $(q)$ as well as the demand for nonhousing consumption $(x)$.

$$
u=u(q, x)
$$

The budget constraint of individuals is considered as follows.

$$
P q+x+M(k, \varnothing)=y
$$

where $P$ is the housing price, $y$ is income, and $k$ is the distance from the epicentre. $\varnothing$ is the health insurance risk premia associated with communicable diseases. $M(k, \varnothing)$ is the total medical cost. Furthermore, we assume the medical cost $M(k, \varnothing)=m k+\varnothing$ where $m$ is the variable cost for medical services and $\varnothing$ is the health insurance risk premia associated with any communicable diseases. Let $n(k)$ be the number of households residing at location $k$ from the epicentre and $\theta(k)=2 \pi k$ be the housing supply at the location $k$ for simplicity. The equality of supply and demand for housing in each location can therefore be represented as $n(k) q=\theta(k)$. Given that the total population must be within the boundary of the city 
and is fixed, we have: $\int_{0}^{b} n(k) d k=N$; where $b$ is the fixed city boundary, and $N$ is the total population.

The closed urban model is then solved following Alonso's theory and Wheaton (1977). While in most applications, an open urban city model is used, in the pandemic period, Wuhan was a closed city, suggesting that a closed model is appropriate. Thus, the bid-rent functions for an individual would be $y-m k-\varnothing=e(P, u)$, where $e(P, u)$ is the minimum expenditure function. Following the model stated above, we can apply the envelope theorem and yields:

$$
\frac{\partial P}{\partial \varnothing}=-\frac{1}{q}<0
$$

The partial equilibrium implies that an increase in health insurance risk premia for communicable diseases $(\varnothing)$ will decrease the bid rent function for individuals. Thus, we hypothesised that: Ceteris paribus, COVID-19, flattens the house price gradient from the epicentre to the urban peripherals.

\section{References}

Alexander, Diane, and Ezra Karger. 2020. Do Stay-at-Home Orders Cause People to Stay at Home? Effects of Stay-at-Home Orders on Consumer Behavior (22 June 2020). FRB of Chicago Working Paper No. 2020-12. Available online: https://ssrn.com/abstract=35 83625 (accessed on 4 March 2021).

Alonso, William. 1964. Location and Land Use: Toward a General Theory of Land Rent. Cambridge: Harvard University Press.

Anas, Alex, and David Pines. 2008. Anti-sprawl policies in a system of congested cities. Regional Science and Urban Economics 38: 408-23. [CrossRef]

Anas, Alex, and Hyok-Joo Rhee. 2006. Curbing excess sprawl with congestion tolls and urban boundaries. Regional Science and Urban Economics 36: 510-41. [CrossRef]

Apergis, Nicholas. 2021. The role of housing market in the effectiveness of monetary policy over the Covid-19 era. Economics Letters 2020: 109749. [CrossRef]

Baker, Scott R., Nicholas Bloom, Steven J. Davis, Kyle J. Kost, Marco C. Sammon, and Tasaneeya Viratyosin. 2020. The Unprecedented Stock Market Impact of COVID-19 (No. w26945). Cambridge: National Bureau of Economic Research.

Bank for International Settlements. 2020. BIS Residential Property Price Statistics, Q2 2020. Available online: https:/ /www.bis.org/ statistics/pp_residential_2011.htm (accessed on 4 March 2021).

Beja, Avraham. 1972. On systematic and unsystematic components of financial risk. The Journal of Finance 27: 37-45. [CrossRef]

Brodeur, Abel, David M. Gray, Anik Islam, and Suraiya Bhuiyan. 2020. A Literature Review of the Economics of COVID-19. IZA Discussion Paper No. 13411. Available online: https: / /ssrn.com/abstract=3636640 (accessed on 4 March 2021).

Brueckner, Jan K. 1987. The structure of urban equilibria: A unified treatment of the Muth-Mills model. Handbook of Regional and Urban Economics 2: 821-45.

Brueckner, Jan K., and Robert W. Helsley. 2011. Sprawl and blight. Journal of Urban Economics 69: 205-13. [CrossRef]

Chen, Kaiji, and Yi Wen. 2017. The great housing boom of China. American Economic Journal: Macroeconomics 9: 73-114. [CrossRef]

Couch, Chris, and Jay Karecha. 2006. Controlling urban sprawl: Some experiences from Liverpool. Cities 23: 353-63. [CrossRef]

D'Lima, Walter, Luis A. Lopez, and Archana Pradhan. 2020. COVID-19 and Housing Market Effects: Evidence from U.S. Shutdown Orders. Available online: https: / ssrn.com/abstract=3647252 (accessed on 4 March 2021).

Del Giudice, Vincenzo, Pierfrancesco De Paola, and Francesco Paolo Del Giudice. 2020. COVID-19 infects real estate markets: Short and mid-run effects on housing prices in Campania region (Italy). Social Sciences 9: 114. [CrossRef]

Del Rio-Chanona, R. Maria, Penny Mealy, Anton Pichler, Francois Lafond, and J. Doyne Farmer. 2020. Supply and demand shocks in the COVID-19 pandemic: An industry and occupation perspective. arXiv arXiv:2004.06759.

Fang, Hanming, Long Wang, and Yang Yang. 2020. Human mobility restrictions and the spread of the novel coronavirus (2019-ncov) in china. Journal of Public Economics 191: 104272. [CrossRef]

Ferguson, Neil, Daniel Laydon, Gemma Nedjati Gilani, Natsuko Imai, Kylie Ainslie, Marc Baguelin, Sangeeta Bhatia, Boonyasiri Adhiratha, Cucunubá Zulma, Cuomo-Dannenburg Gina, and et al. 2020. Report 9: Impact of Non-Pharmaceutical Interventions (NPIs) to Reduce COVID19 Mortality and Healthcare Demand. London. Available online: https://spiral.imperial.ac.uk/ bitstream/10044/1/77482/14/2020-03-16-COVID19-Report-9.pdf (accessed on 4 March 2021).

Francke, Marc, and Matthijs Korevaar. 2020. Housing Markets in a Pandemic: Evidence from Historical Outbreaks. Available online: https: / / ssrn.com/abstract=3566909 (accessed on 4 March 2021).

Glaeser, Edward L., and Matthew E. Kahn. 2004. Sprawl and urban growth. In Handbook of Regional and Urban Economics. Amsterdam: Elsevier, vol. 4, pp. 2481-527.

Gong, Yifan, and Charles Ka Yui Leung. 2020. When education policy and housing policy interact: Can they correct for the externalities? Journal of Housing Economics 50: 101732. [CrossRef]

Gopinath, Gita. 2020. Limiting the economic fallout of the coronavirus with large targeted policies. In Mitigating the COVID Economic Crisis: Act Fast and Do Whatever It Takes. London: CEPR Press, pp. 41-48. 
Hanushek, Eric, and Kuzey Yilmaz. 2007. The complementarity of Tiebout and Alonso. Journal of Housing Economics 16: $243-61$. [CrossRef]

Huang, Chaolin, Yeming Wang, Xingwang Li, Llili Ren, Jianpinng Zhao, Yi Hu, Li Zhang, Guohui Fan, Jiuyang Xu, Xiaoying Gu, and et al. 2020a. Clinical features of patients infected with 2019 novel coronavirus in Wuhan, China. Lancet 395: 497-506. [CrossRef]

Huang, Naqun, Jindong Pang, and Yanmin Yang. 2020b. The Impact of the COVID-19 Epidemic on the Housing Market in China. Available online: https: / / ssrn.com/abstract=3642444 (accessed on 4 March 2021).

Jaeger, Jochen AG, and Christian Schwick. 2014. Improving the measurement of urban sprawl: Weighted Urban Proliferation (WUP) and its application to Switzerland. Ecological Indicators 38: 294-308. [CrossRef]

Knight Frank. 2020. Global House Price Index, Research, Q2 2020. Available online: https://www.bayleys.co.nz/media/bdf9502b-cb9 6-4015-af53-6a5bcf548416 (accessed on 4 March 2021).

Koren, Miklós, and Rita Pető. 2020. Business Disruptions from Social Distancing. Available online: https://arxiv.org/pdf/2003.13983 .pdf (accessed on 4 March 2021).

Leung, Charles Ka Yui, Siu Kei Wong, and Patrick Wai Yin Cheung. 2007. On the stability of the implicit prices of housing attributes: A dynamic theory and some evidence. International Real Estate Review 10: 65-91.

Leung, Charles Ka Yui, Patrick Wai Yin Cheung, and Edward C.H. Tang. 2011. Financial Crisis and the Comovements of Housing Sub-Markets: Do Relationships Change after a Crisis? Available online: https://mpra.ub.uni-muenchen.de/id/eprint/31627 (accessed on 4 March 2021).

Ling, David C., Chongyu Wang, and Tingyu Zhou. 2020. A first look at the impact of COVID-19 on commercial real estate prices: Asset-level evidence. The Review of Asset Pricing Studies 10: 669-704. [CrossRef]

Liu, Ding, Weihong Sun, and Xuan Zhang. 2020. Is the Chinese economy well positioned to fight the COVID-19 pandemic? The financial cycle perspective. Emerging Markets Finance and Trade 56: 2259-76. [CrossRef]

Malpezzi, Stephen. 2002. Hedonic pricing models: A selective and applied review. In Housing Economics and Public Policy. Boston: Blackwell Science Ltd., pp. 67-89.

Manzoli, Elisabetta, and Sauro Mocetti. 2019. The House Price Gradient: Evidence from Italian Cities. Italian Economic Journal 5: 281-305. [CrossRef]

Marona, Bartłomiej, and Mateusz Tomal. 2020. The COVID-19 pandemic impact upon housing brokers' workflow and their clients' attitude: Real estate market in Krakow. Entrepreneurial Business and Economics Review 8: 221-32. [CrossRef]

Mazur, Mieszko, Man Dang, and Miguel Vega. 2021. COVID-19 and the march 2020 stock market crash. Evidence from S\&P1500. Finance Research Letters 38: 101690.

McKibbin, Warwick, and Roshen Fernando. 2020. The economic impact of COVID-19. In Economics in the Time of COVID-19. London: CEPR Press, p. 45.

Mieszkowski, Peter, and Edwin S. Mills. 1993. The causes of metropolitan suburbanisation. Journal of Economic Perspectives 7: 135-47. [CrossRef]

Mills, Edwin S. 1967. An aggregative model of resource allocation in a metropolitan area. The American Economic Review 57: 197-210.

Muth, Richard F. 1969. Cities and Housing: The Spatial Pattern of Urban Residential Land Use. Chicago: University of Chicago Press.

Nicola, Maria, Zaid Alsafi, Catrin Sohrabi, Ahmed Kerwan, Ahmed Al-Jabir, Christos Iosifidis, Maliha Agha, and Riaz Agha. 2020. The socio-economic implications of the coronavirus pandemic (COVID-19): A review. International Journal of Surgery 78: 185-93. [CrossRef]

O'Sullivan, Arthur. 2007. Urban Economics, 6th ed. New York: McGraw Hill.

Ozili, Peterson K., and Thankom Arun. 2020. Spillover of COVID-19: Impact on the Global Economy (27 March 2020). Available online: https: / / ssrn.com/abstract=3562570 (accessed on 4 March 2021).

Qian, Xianhang, Shanyun Qiu, and Guangli Zhang. 2021. The Impact of COVID-19 on Housing Price: Evidence from China. Finance Research Letters, 101944, in press. [CrossRef]

Sina. 2020. 2019 Wuhan property market illustration: residential volume and price rise, office building competition intensifies, the “first-store economy" promotes the recovery of retail properties (2019年武漢樓市圖鑑 : 住宅量價齊升辦公樓競爭加劇 首店經 濟促零售物業回暖). January 17. Available online: https://news.sina.com.tw/article/20200117/34019206.html (accessed on 4 March 2021).

So, Mike KP, Amanda MY Chu, and Thomas WC Chan. 2021. Impacts of the COVID-19 pandemic on financial market connectedness. Finance Research Letter 38: 101864. [CrossRef]

Stulz, René M. 1996. Rethinking risk management. Journal of Applied Corporate Finance 9: 8-25. [CrossRef]

Susskind, Daniel, and David Vines. 2020. The economics of the COVID-19 pandemic: An assessment. Oxford Review of Economic Policy 36: S1-S13. [CrossRef]

Tanrıvermiş, Harun. 2020. Possible impacts of COVID-19 outbreak on real estate sector and possible changes to adopt: A situation analysis and general assessment on Turkish perspective. Journal of Urban Management 9: 263-69. [CrossRef]

Tuzel, Selale, and Miao Ben Zhang. 2017. Local risk, local factors, and asset prices. The Journal of Finance 72: 325-70. [CrossRef]

Uchehara, Ikechukwu, Mansur Hamma-Adama, Kwadwo Ayeh Obiri, Naeimeh Jafarifar, and David Moore. 2020. Impacts and risk management of COVID-19 pandemic on real estate supply chain. International Journal of Real Estate Studies 14: 41-53. 
United Nations Office for Disaster Risk Reduction (UNODRR). 2020. Review of COVID-19 Disaster Risk Governance in Asia-Pacific: Towards Multi-Hazard and Multi-Sectoral Disaster Risk Reduction. Geneva: World Health Organization, Available online: https: / /www. undrr.org/publication/review-covid-19-disaster-risk-governance-asia-pacific-towards-multi-hazard-and-multi (accessed on 4 March 2021).

Viscusi, W. Kip. 2020. Pricing the global health risks of the COVID-19 pandemic. Journal of Risk and Uncertainty 61: 101-28. [CrossRef] Von Thünen, Johann. 1826. Isolated State. Translated by Carla M. Wartenberg. Oxford: Pergamon Press.

Wang, Bingbing. 2021. How Does COVID-19 Affect House Prices? A Cross-City Analysis. Journal of Risk and Financial Management 14: 47. [CrossRef]

Wheaton, William C. 1977. A bid rent approach to housing demand. Journal of Urban Economics 4.2: 200-217. [CrossRef]

World Health Organization. 2020. Origin of SARS-CoV-2. In WHO/2019-nCoV/FAQ/Virus_origin/2020.1. Geneva: World Health Organization, Available online: https:/ /www.who.int/publications/i/item/origin-of-sars-cov-2 (accessed on 4 March 2021).

Wong, Grace. 2008. Has SARS Infected the Property Market?Evidence from Hong Kong. Journal of Urban Economics 63: 74-95. [PubMed]

Wuhan Municipal Health Commission. 2020. Wuhan COVID-19 Infected Numbers Report (1 August 2020). Available online: http:/ / wjw.wuhan.gov.cn/ztzl_28/fk/tzgg/202008/t20200802_1414093.shtml (accessed on 4 March 2021).

Yang, Minhua, and Junni Zhou. 2021. The impact of COVID-19 on the housing market: Evidence from the Yangtze river delta region in China. Applied Economics Letters, 1-4. [CrossRef]

Yiu, Chung Yim, and Siu Kei Wong. 2005. The Effects of Expected Transport Improvements on Housing Prices. Urban Studies 42: 113-25. [CrossRef]

Yoruk, Baris. 2020. Early Effects of the COVID-19 Pandemic on Housing Market in the United States (21 May 2020). Available online: https: / / ssrn.com/abstract=3607265 (accessed on 4 March 2021).

Zhang, Dayong, Min Hu, and Qiang Ji. 2020. Financial markets under the global pandemic of COVID-19. Finance Research Letters 36: 101528. [CrossRef] [PubMed]

Zhao, Yunhui. 2020. US Housing Market During COVID-19: Aggregate and Distributional Evidence (September 1. 2020). IMF Working Paper No. 2020/212. Available online: https:/ /ssrn.com/abstract=3744679 (accessed on 4 March 2021). 